УДК 343.364

DOI https://doi.org/10.32849/2663-5313/2021.1.42

\title{
Михайло Борусовсъкий,
}

аспірант кафедри кримінального процесу та криміналістики

факультету № 1

Інституту з підготовки фахівщів для підрозділів Нащіональної поліції

Львівського державного університету внутрішніх справ

\section{ОБСТАВИНИ, ЩО ПІДЛЯГАЮТЬ ВСТАНОВЛЕННЮ ПІД ЧАС РОЗСЛІДУВАННЯ ЗЛОВЖИВАННЯ ВЛАДОЮ АБО СЛУЖБОВИМ СТАНОВИЩЕМ СУДДЕЮ ПІД ЧАС ЗДІЙСНЕННЯ ПРАВОСУДДЯ}

Наукову статтю присвячено висвітленню питання щодо обставин, що підлягають встановленню під час розслідування зловживання владою або службовим становищем суддею під час здійснення правосуддя. Проаналізовано підходи вчених до поняття обставин, що підлягають встановленню, встановлено, що є думка про ототожнення досліджуваного поняття з криміналістичною характеристикою кримінальних правопорущень, і підкреслено їх розмежування на підставі завдань, котрі вони виконують під час формування криміналістичної методики окремих кримінальних правопорущень. Встановлено, що формування обставин, які підляаюоть встановленню, зумовлено трьома чинниками: предметом доказування (передбаченим ст. 91 КПК України), кримінально-правовою та криміналістичною характеристиками певного кримінального правопорушення. При цьому обставини, що підлягають доказуванню, відображені в нормах чинного КПК та є визначальними, базовими для всіх кримінально-протиправних діянь без винятку, а також для криміналістичної методики розслідування, тому мають неабияке значення. Проведено класифікаиію обставин, що підлягають встановленню під час розслідування зловживання владою або службовим становищем суддею під час здійснення правосуддя, котрі об'єднано у п'ять груп: обставини про особу злочиния та потерпілого; обставини про подію кримінального правопорушення; обставини про мотив та мету кримінального правопорушення; обставини щодо судового рішення; інші обставини, які у свою чергу включають у себе окремі обставини, що підлягають встановленню. На підставі аналізу судової практики у кримінальних провадженнях про зловживання владою або службовим становищем суддею під час здійснення правосуддя здійснено детальну характеристику обставин кожної групи. Доведено, що обставини, що підлягають встановленню, як елемент криміналістичної методики розслідування зловживання владою або службовим становищем суддею під час здійснення правосуддя, дає змогу більш иілеспрямовано та з меншими витратами зусиль та часу визначити коло інформачії, яку необхідно встановити; вивчити необхідні матеріали, оцінивши їх законність та достатність, з метою визначення напрямів подальшого пошуку та процесуальних рішень та здійснення процесуальних дій на окремих етапах кримінального провадження.

Ключові слова: розслідування, кримінальне провадження, суддя, зловживання владою, службові повноваження, обставини, встановлення.

Постановка проблеми. Упродовж тривалого часу існування криміналістика накопичила чималі знання, що стосуються методики розслідування злочинів, зокрема злочинів проти правосуддя. Проте сьогодні відчувається, що методика розслідування зловживання владою або службовим становищем суддею під час здійснення правосуддя, зокрема в частині формування обставин, які підлягають встановленню під час розслідування цього виду кримінального правопорушення, не досить розроблена.

Аналіз останніх досліджень і публікацій. Предмет доказування, а також зміст обста- вин, що підлягають встановленню у кримінальних провадженнях, неодноразово аналізували вітчизняні й зарубіжні вчені в галузі кримінального процесу та криміналістики, зокрема: Ю. П. Аленін, В. П. Бахін, Р. С. Бєлкін, В. І. Галаган, Л. Я. Драпкін, В. С. Зеленецький, В. С. Кузьмічов, В. В. Лисенко, Г. А. Матусовський, В. О. Образцов, М. В. Салтевський, В. Ю. Шепітько та інші.

Метою статті є розгляд обставин, що підлягають встановленню під час розслідування зловживання владою або службовим становищем суддею під час здійснення правосуддя. 
Виклад основного матеріалу. У криміналістиці тривають дискусії про те, чи варто розглядати обставини, що підлягають встановленню, як самостійний елемент окремої методики розслідування або відображати їх у складі криміналістичної характеристики кримінальних правопорушень.

Так, одні автори вважають, що криміналістична характеристика та обставини, що підлягають встановленню, є поняттями тотожними та останні є навіть їі складовим елементом, і тому немає потреби окремо виділяти обставини, що підлягають встановленню, та включати їх до структури окремої криміналістичної методики [1, с. 274].

Інші автори дотримуються протилежної позиції, вважаючи за необхідне виділяти обставини, що підлягають встановленню, в структурі окремої криміналістичної методики, підкресливши, що для цілеспрямованого розслідування слідчий повинен у кожному кримінальному провадженні уявити собі, що саме необхідно з'ясувати, тобто які саме фактичні обставини розслідуваної події повинні бути встановлені і в яких межах [2, с. 84].

Ми ж, поділяючи думку В. В. Тіщенка, вважаємо, що у методиці розслідування окремих категорій злочинів обставини, що підлягають встановленню, мають криміналістичне значення, оскільки зумовлюють кінцеві завдання розслідування, спрямованість слідчих версій, постановку проміжних завдань розслідування на його різних етапах і в різних слідчих ситуаціях [3, с. 208].

Щодо кола обставин, що підлягають встановленню, то М. О. Селіванов пропонує, визначаючи коло обставин, що підлягають встановленню, використовувати елементи предмета доказування, що містяться в кримінально-процесуальному законі [4, с. 191]. На думку А. І. Кунтія, найважливіші і найбільш загальні з таких обставин закріплені в ст. 91 КПК України, але перелік цих обставин не враховує особливості різновидів і груп злочинів, змісту складу злочинів, різнобічних відомостей про особи злочинця і потерпілого, інших факторів. Тому формування обставин, що підлягають встановленню, зумовлено трьома чинниками: предметом доказування (ст. 91 КПК України), кримінально-правовою та криміналістичною характеристиками певного кримінального правопорушення. При цьому обставини, що підлягають доказуванню, відображені в нормах чинного КПК та $є$ визначальними, базовими для всіх злочинних діянь без винятку, а також для криміналістичної методики розслідування, тому мають неабияке значення [5, с. 80-81].
Тому, враховуючи позицію зазначеного дослідника, вважаємо, що обставини, що підлягають встановленню під час розслідування кримінального провадження про зловживання владою або службовим становищем суддею під час здійснення правосуддя, на нашу думку, доцільно об'єднати у п'ять груп:

1. Обставини про особу злочиния та потерпілого:

1.1. відомості про особу злочинця:

- відомості про склад суду (одноособово чи колегіально; суд присяжних);

- підстави та час набуття особою статусу судді (слідчого судді) відповідного суду, його права та обов'язки;

- підстави та час набуття особою статусу судді (слідчого судді, члена колегії суддів) у конкретному провадженні, реквізити судової справи, їі обставини та учасники;

- чи притягався суддя до будь-якого виду дисциплінарної відповідальності в ході виконання службових повноважень;

- чи звертався суддя з повідомленням про втручання в його діяльність щодо здійснення правосуддя до Вищої ради правосуддя, до Генерального прокурора (цей обов'язок прописаний у ч. 4 ст. 48 ЗУ «Про судоустрій та статус суддів».

- відомості щодо розподілу ролей між суддями у разі колегіального розгляду справи (з'ясування обставини формування змови між співучасниками, того, хто запропонував вчинити злочин певним способом, де та коли це відбулося, ким і які ролі були визначені та між ким зі співучасників розподілені, яка винагорода кожному була попередньо визначена та фактично здійснена);

- відомості щодо виду та розміру винагороди;

1.2. відомості про потерпілого (-их).

1.3. наявність причинного зв'язку між діями винних осіб та їх наслідками;

- виявлення причин й умов, які сприяли вчиненню злочину;

- відомості про наявність зв’язку «потерпілий - злочинець»;

- наявність причинного зв'язку між діями судді щодо зловживання владою або службовими повноваженнями у формі постановлення судового рішення та наслідками такого рішення.

Приклад обставин, що належать до першої класифікаційної групи, знаходимо у вироку Чигиринського районного суду Черкаської області від 7 квітня 2015 р. ОСОБА_2 засуджено за ч. 2 ст. 364 , ч. 2 ст. 375 КК У країни за злочин, вчинений з корисливих мотивів, який полягав у зловживанні владою суддею у формі винесення суддею завідомо неправосудного рішення без заявлення самовідводу 
у цивільних справах щодо визнання права власності на об'єкти нерухомості - нежитлові приміщення, що належали її матері [6].

2. Обставини про подію кримінального правопорушення. До цієї категорії слід зараховувати:

2.1. відомості про предмет зловживання владою або службовим становищем суддею;

2.2. час та місце зловживання владою або службовим становищем суддею (слідчим суддею, суддями);

2.3. відомості про спосіб вчинення злочину (спосіб готування, безпосереднього вчинення та його приховання);

2.4. відомості про засоби вчинення кримінального правопорушення (приміром, стосовно подальших обставин, які підлягають встановленню, зазначимо, що встановленню підлягають просторово-часові й інші параметри дій, спрямованих не тільки на безпосередню реалізацію злочинного задуму, спрямованого на зловживання владою або службовим становищем, що може проявитися у постановленні судового рішення, а й на готування та приховування слідів злочину. Якщо злочин вчинений за попередньою змовою з іншими суддями, під час колегіального розгляду справи, встановленню підлягають дії, які були вчинені кожним суддею під час готування, вчинення та приховування по кожному епізоду їхньої спільної злочинної діяльності;

2.5. характер протиправних дій, які були вчинені суддею (слідчим суддею, суддями) під час здійснення правосуддя, тобто які грубі порушення норм процесуального закону мали місце з боку судді (слідчого судді, суддів) та/або неправильне застосування норм матеріального права, чи мала місце невідповідність висновків судді (слідчого судді, суддів) фактичним обставинам справи та як вони вплинули на зміст судового акта;

2.6. умови, що спричинили виникнення та формування прямого умислу судді (слідчого судді, суддів) на зловживання владою або службовим становищем;

2.7. відомості про матеріальні й ідеальні сліди відображення готування, вчинення та приховування кримінального правопорушення;

3. Обставини про умисел, мотив та мету кримінального правопорушення.

3.1. вчинені з корисливих мотивів (поєднані з отриманням неправомірної вигоди). Так, вироком Чигиринського районного суду Черкаської області від 7 квітня 2015 р. ОСОБА 2 засуджено за ч. 2 ст. 364 , ч. 2 ст. 375 КК України. За обставинами справи, достовірно знаючи та усвідомлюючи, що сторонами у цивільних справах є близькі родичі (мати і племінниця), що відповідно до закону унеможливлює участь судді у розгляді цих цивільних справ та зумовлює відвід судді (самовідвід), ОСОБА_2 не здійснила жодних дій та не прийняла відповідних процесуальних рішень щодо заявлення самовідводів у зазначених цивільних справах, незважаючи на те, що справи не підсудні Ленінському районному суду м. Кіровограда (оскільки позови, що виникають 3 приводу нерухомого майна, пред'являються за місцезнаходженням майна або основної його частини, тоді як зазначені об'єкти нерухомого майна розташовані на території Кіровського району м. Кіровограда), у найкоротший строк призначила їх попередні розгляди, створила умови неявки сторін провадження до суду, не дослідила докази і в результаті винесла неправосудне судове рішення, яким повністю задовольнила позовні вимоги позивача - власної матері, керуючись при цьому корисливими мотивами та, окрім того, спричинивши тяжкі наслідки для громадських інтересів у вигляді неправомірного визнання права власності на майно територіальної громади - нежитлові підвальні приміщення, загальна вартість яких на момент прийняття неправосудного рішення відповідно до висновку експерта складала 239672 грн [6].

3.2. дії, що спричинили тяжкі наслідки. Так, М. І. Хавронюк до тяжких наслідків відносить позбавлення волі, обмеження волі чи арешт потерпілого як результат неправосудного вироку, самогубство потерпілого чи його тяжке захворювання, викликане стресовою ситуацією, пов'язаною із винесенням неправосудного рішення, обмеження потерпілого в його конституційних правах (зокрема, позбавлення права власності на житло чи батьківських прав, визнання обмежено осудним тощо), а також спричинення [7, с. 289-290]. До прикладу, вироком Летичівського районного суду Хмельницької області від 22 січня 2013 р. ОСОБА_1 засуджено, зокрема, за ч. 2 ст. 364 , ч. 1 ст. $\overline{3} 75$ КК, при цьому тяжкими наслідками вчиненого ним цього злочину суд визнав проведення на підставі судового рішення, постановленого ОСОБА 1, незаконних виплат за рахунок бюджетних коштів у загальній сумі 6485644 грн. [8].

3.3. дії в інших особистих інтересах. Як приклад із судової практики можна назвати те, що суддя обвинувачувався у вчиненні злочинів, передбачених ч. 1 ст. 375, ч. 1 ст. 375 , ч. 2 ст. 375 , ч. 1 ст. 364 , ч. 1 ст. 366 КК України. Обвинувачення грунтувалося на тому, що суддя, зловживаючи владою, діючи «в особистих інтересах» (штучне створення уявлення про дотримання присяги судді, належне виконання ним обов'язків), склав та приєд- 
нав до матеріалів справи ухвалу про призначення розгляду заяви на 10 годину 4 червня 2008 року, яку датував 3 червня 2008 року. Фактично вказана ухвала була складена суддею 4 червня 2008 року. 4 червня 2008 року суддя постановив ухвалу про встановлення способу і порядку виконання постанови суду від 13 липня 2007 року. При цьому суддя достовірно знав, що ще 3 червня 2008 року за його вказівкою помічник судді виготовив ухвалу про встановлення способу і порядку виконання постанови суду від 13 липня 2007 року, а її копію видав учаснику без судового розгляду вказаної заяви. Крім того, за вказаних умов і обставин 4 червня 2008 року суддя, зловживаючи владою і службовим становищем, вилучив 3 матеріалів справи ухвалу від 3 червня 2008 року про встановлення порядку виконання постанови суду від 13 липня 2007 року й видав завідомо недостовірну ухвалу від 4 червня 2008 року [9].

Іншими особистими інтересами можуть бути також i неприязнь або навпаки до певної особи або групи осіб. Наприклад, у постанові колегії суддів Касаційного кримінального суду від 26 червня 2018 р., згідно 3 пред'явленим обвинуваченням, суддя ОСОБА_3, будучи службовою особою і носієм судової влади, свідомо і цілеспрямовано використовуючи своє службове становище всупереч інтересам правосуддя, розраховуючи одержати для себе неправомірну вигоду у вигляді подальшого сприяння невстановленими слідством особами з числа вищого керівництва у державі в кар'єрному рості, яке могло відбутися після успішного виконання злочинного завдання на грунті сформованого враження про них як про прихильників чинної на той час влади, склав, підписав, постановив та проголосив у судовому засіданні завідомо неправосудну постанову. На обгрунтування наявності такого мотиву сторона обвинувачення не встановила і не надала суду жодного доказу того, в чому саме полягав кар'єризм ОСОБА_3 - ні взагалі, ні щодо винесення постанови - та які дії вживалися ОСОБА_3 для реалізації цього мотиву, як вплинуло винесення ним зазначеної постанови на його кар'єрний ріст. Судом першої інстанції на підставі дослідження даних про роботу на посаді судді ОСОБА_3 встановлено, що він за весь час роботи суддею в Одеському окружному адміністративному суді із заявою чи проханням про переведення до іншого суду не звертався, питання про його звільнення не вирішувалось, його кандидатура на адміністративну посаду в суді не розглядалася і наміру такого останній ніколи не виявляв; задовго до вказаних в обвинувальному акті подій ОСОБА_3 був обраний на посаду судді безстроково, а тому не був обтяжений процедурою обрання на посаду на момент вчинення інкримінованого йому діяння [10].

4. Обставини щодо судового рішення, що винесене в результаті зловживання владою або службовим становищем суддею:

4.1. чи набуло законної сили судове рішення, якщо так, то які обставини його виконання та наслідки цього, чи мають вони характер тяжких для особи, щодо прав, свобод та інтересів якої він був постановлений, який ступінь тяжкості шкоди здоров’ю, розмір матеріальних збитків, моральної шкоди;

4.2. чи було оскарження судового рішення учасниками провадження, коли це сталося, які результати судового розгляду в суді апеляційної/касаційної інстанції, зміст судового акта, який був постановлений вищою судовою інстанцією, обставини та результати його виконання, зокрема, чи було припинене порушення прав, свобод особи;

4.3. чи було звернення особи (осіб) до Вищої Ради правосуддя зі скаргою на дії, рішення судді (суддів) та які результати розгляду такої скарги цим органом;

4.4. наслідки, що настали в результаті зловживання владою або службовим становищем під час здійснення правосуддя.

5. Інші обставини. Серед інших обставин, що мають значення для вирішення завдань кримінального провадження досліджуваної категорії, необхідно виділити:

5.1. обставини, що виключають факт вчинення підозрюваною особою іншого виду кримінального правопорушення (ст. 366 , 368 КК України тощо);

5.2. обставини, що обтяжують чи пом'якшують покарання;

5.3. обставини, що виключають кримінальну відповідальність чи є підставою для закриття кримінального провадження;

5.4. обставини, що є підставою для звільнення від кримінальної відповідальності, а також обставини, що виключають факт учинення підозрюваною особою іншого кримінального правопорушення.

3-поміж обставин, що впливають на ступінь тяжкості вчинення злочину та обставин, які пом'якшують покарання, як такі, що підлягають встановленню, слід зазначити: з'явлення із зізнанням, щире каяття або активне сприяння розслідуванню злочину, а також добровільне відшкодування завданого збитку або усунення заподіяної шкоди (що, як наслідок, може розглядатись як підстава для укладення угоди про примирення); вчинення злочину жінкою в стані вагітності; вчинення злочину внаслідок збігу тяжких особистих, сімейних чи інших обставин; вчинення зло- 
чину під впливом погрози, примусу або через матеріальну, службову чи іншу залежність; вчинення злочину з перевищенням меж крайньої необхідності. Також 3-поміж обставин, що впливають на ступінь тяжкості вчинення злочину, та обставин, які обтяжують покарання, як такі, що підлягають встановленню, слід зазначити: тяжкі наслідки, завдані злочином, вчинення злочину з використанням умов воєнного або надзвичайного стану, інших надзвичайних подій.

Стосовно обставин, що є підставою для звільнення від кримінальної відповідальност або покарання, щодо досліджуваного нами виду кримінального правопорушення можуть застосовуватись підстави, передбаченні розділами IX та XII КК України, якщо такі фактично були й можуть застосовуватися.

\section{Висновок}

Таким чином, у результаті дослідження ми дійшли висновку про те, що обставини, що підлягають встановленню, є елементом криміналістичної методики розслідування зловживання владою або службовим становищем суддею під час здійснення правосуддя, який дає змогу більш цілеспрямовано та з меншими витратами зусиль та часу визначити коло інформації, яку необхідно встановити, вивчити необхідні матеріали, оцінивши їх законність та достатність, 3 метою визначення напрямів подальшого пошуку та процесуальних рішень та здійснення процесуальних дій на окремих етапах кримінального провадження.

\section{Список використаних джерел:}

1. Белкин Р.С. История отечественной криминалистики. Москва : Знание, 1999. 496 с.

2. Танасевич В.Г. Значение криминалистической характеристики преступлений и следственных ситуаций для методики расследования преступлений. Актуальные проблемы советской криминалистики. Москва, 1980. С. 84-93.

3. Тіщенко В.В. Корисливо-насильницькі злочини : криміналістичний аналіз. Одеса : Юридична література, $2002.360 \mathrm{c}$.

4. Справочная книга криминалиста / рук автор. кол. и отв. ред. Н. А. Селиванов. Москва: HOPMA, 2000. 727 c

5. Кунтій А.І. Методика розслідування умисного вбивства, вчиненого в стані сильного душевного хвилювання : монографія. Львів : ЛьвДУВС 2016. 227 c.

6. Вирок Чигиринського районного суду Черкаської області від 7 квітня 2015 р. URL : http://www.reyestr.court.gov.ua/Review/43831707 (дата звернення: 19.12.2020)

7. Корупційні схеми: іх кримінально-правова кваліфікація і досудове розслідування / за ред. М.I. Хавронюка. Київ : Москаленко О. М., 2019. 464 с.

8. Вирок Летичівського районного суду Хмельницької області від 22 січня 2013 р. URL: http://www.reyestr.court.gov.ua/Review/36788997 (дата звернення: 19.12.2020)

9. Вирок апеляційного суду Харківської області від 31 січня 2011 року. URL: http://www. reyestr.court.gov.ua/Review/24901107 (дата звернення: 19.12.2020)

10. Постанова колегії суддів Касаційного кримінального суду від 26 червня 2018 р. URL: http://www.reyestr.court.gov.ua/Review/75099762 (дата звернення: 19.12.2020)

Mykhaylo Borusovskiy. Circumstances to be established during the investigation of an abuse of authority or official position by a judge during execution

The scientific article is devoted to the issue of circumstances to be established during the investigation of abuse of power or official position by a judge in the administration of justice. The approaches of scientists to the concept of circumstances to be established are analyzed, the opinion on the identification of the studied concept with the forensic characteristics of crimes is established and their differentiation is emphasized, based on the tasks they perform during the formation of forensic methods of individual criminal offenses. It is established that the formation of circumstances to be established is due to three factors: the subject of proof (provided for in Article 91 of the CPC of Ukraine), criminal law and forensic characteristics of a particular criminal offense. At the same time, the circumstances to be proved are reflected in the norms of the current $C P C$ and are decisive, basic for all criminal acts without exception, as well as for forensic methods of investigation, so they are of great importance. The classification of circumstances to be established during the investigation of abuse of power or official position by a judge in the administration of justice, which are grouped into five groups: the circumstances of the identity of the offender and the victim; circumstances of the event of a criminal offense; circumstances about the motive and purpose of the criminal offense; circumstances regarding the court decision; other circumstances, which in turn include certain circumstances to be established. Based on the analysis of judicial practice in criminal proceedings on abuse of power or of ficial position by a judge in the administration of justice, a detailed description of the circumstances of each group. It is proved that the circumstances to be established, as an element of the forensic methodology of investigation of abuse of power or official position by a judge in the administration of justice, allows to more purposefully and with less effort and time to determine the range of information to be established. legality and sufficiency in order to determine the directions of further search and adoption of procedural decisions and the implementation of procedural actions at certain stages of criminal proceedings.

Key words: investigation, criminal proceedings, judge, misfeasance, official powers, circumstance, installation. 